\title{
Life on the edge for the Indian dentist: a look at infection control and its application for Indian dental offices
}

\author{
Anand F Farias ${ }^{1}$, Sajni Rai ${ }^{2}$, Taru Rao ${ }^{3}$ \\ 1. Dept of Prosthodontics, Srinivas Institute of Dental Sciences, Srinivas Integrated Campus, \\ Srinivas Nagar, Mukka, Surathkal, Mangalore, India
}

2. Dept of Prosthodontics, AB Shetty Memorial Institute of Dental Sciences, Deralakatte, Mangalore, India

3. Dept of Dental Materials, AB Shetty Memorial Institute of Dental Sciences, Deralakatte, Mangalore, India

\begin{abstract}
Dental health personnel are constantly exposed to the potential threat of developing an infection by occupational exposures to a variety of microbial pathogens, most common of all are hepatitis B virus (HBV), hepatitis $\mathrm{C}(\mathrm{HCV})$, tuberculosis (TB) and acquired immunodeficiency syndrome (AIDS). Literature has detailed how globally private practices do not always follow all infection control procedure despite numerous guidelines and regulations being published. Infection control practices in Indian dental clinics are said to be years behind the guidelines prescribed by regulatory bodies in the Western World. Researchers have reported on the lax attitudes of dentists in India regarding management of biomedical wastes.
\end{abstract}

This review attempts to assess the possible sources of infection in a dental clinic setting and relate them to a dental clinic in India, and provide the reader with an insight to implement and monitor infection control protocols in the Indian dental setting

Keywords: Disinfection; Dental offices; Cross infection; Infection control, dental

\section{Corresponding Author}

Dr Anand Farias

Associate Professor, Dept. of Prosthodontics, Srinivas Institute of Dental Sciences

Srinivas Integrated Campus, Srinivas Nagar, Mukka, Surathkal, Mangalore 575021, India

Email: anandfarias@hotmail.com 


\section{Introduction}

All dental health care personnel (DHCP), both on the clinical and laboratory fronts, are exposed to the potential threat of developing an infection by occupational exposure to a variety of microbial pathogens, most common of all are hepatitis $B$ virus (HBV), hepatitis C (HCV), tuberculosis (TB) and acquired immunodeficiency syndrome (AIDS). ${ }^{1-3}$

Apart from maxillofacial surgery, the potential for cross infection is highest in the prosthodontic environment. A report by Powel et al. ${ }^{4}$ stated that $67 \%$ of all materials sent from dental offices to the dental laboratories were contaminated with bacteria of varying degrees of opportunistic pathogenicity. Other authors have raised similar views stating the age of patients presenting for prosthodontic treatment to materials and techniques used in prosthodontics as reasons for a higher rate of cross-infection risk. ${ }^{5-6}$

\section{Rationale and Focus}

An initial review of literature showed that globally, many a time, private practices do not always follow all infection control procedure despite various regulatory bodies and textbooks on material science, clinical and laboratory dentistry publishing exhaustive guidelines on infection control in the clinical and laboratory setups for dentistry. It is worrying that sometimes students and even practicing dentists are not aware of cross-infection protocols. ${ }^{7-22}$ Cross infection control practices in Indian dental clinics are still years behind the guidelines prescribed by regulatory bodies in the Western World. ${ }^{23}$ Researchers have reported on the lax attitudes of dentists in India regarding management of biomedical wastes. ${ }^{24-25}$

The goal of this review was to assess the possible sources of infection in a dental clinic setting and relate them to a dental clinic setup in India, and provide the reader with an insight to implement and monitor infection control protocols in the Indian dental setting.

\section{Potential Sources of infection in the Dental Office}

Dental treatment requires close coordination between the dentist, the clinical assistant, and the technical staff. It is between these entities and the patient that cross-infection can occur. ${ }^{1,26}$ In turn these individuals can transmit the infection onto their families and to the general public. Infection from the dental clinic can also be transmitted to the dental laboratory via soiled impressions, casts, prosthesis and instruments (Figure 1).

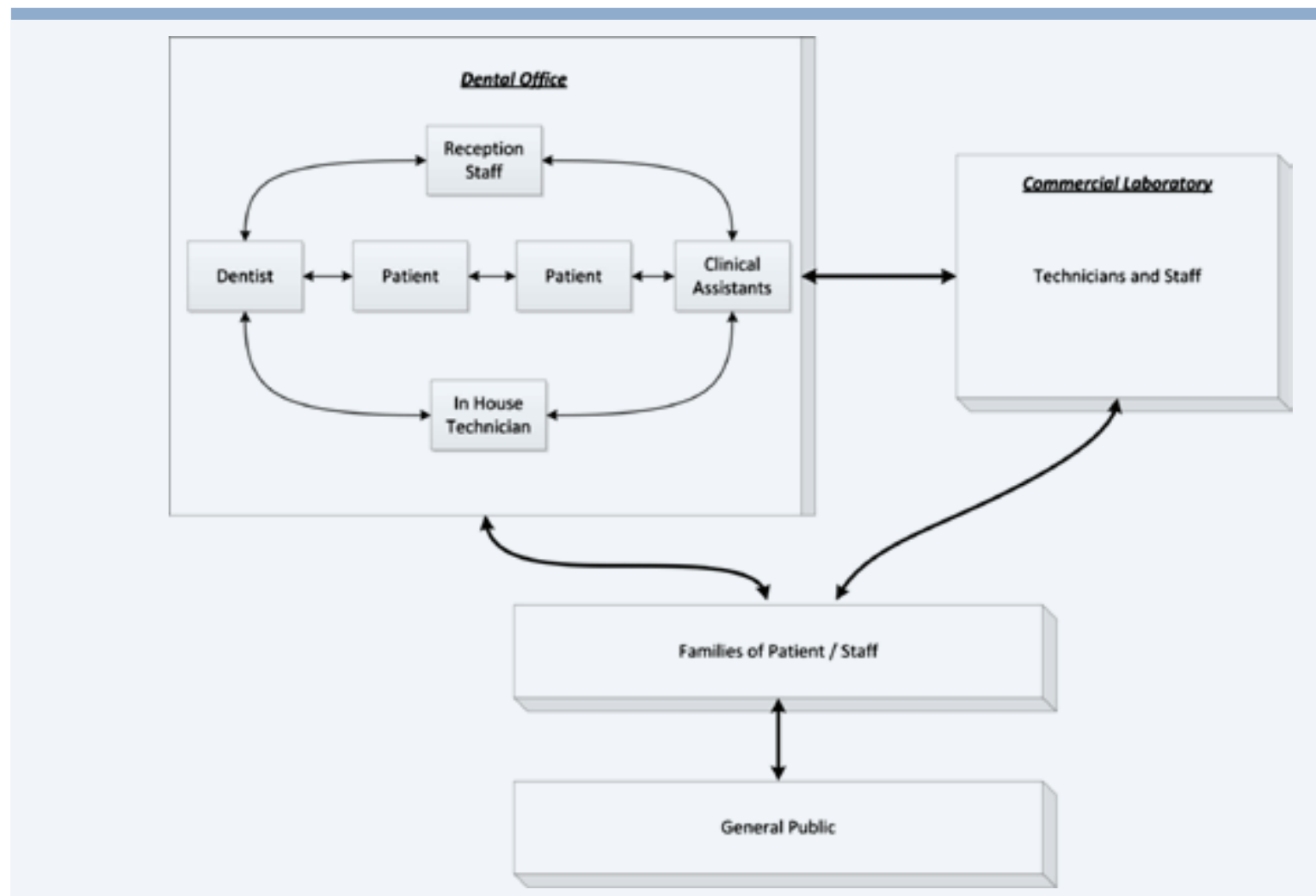

Figure 1. Workflow and spread of infection in the dental setting 
Precautions and cross infection control in the dental office will need to follow the basic principles of infection control: (1) aseptic techniques (2) patient screening and evaluation (3) surface disinfection (4) equipment asepsis and (5) laboratory asepsis. ${ }^{6}$ Implementation of these principles will require the adherence to system of standard infection control protocols.

\section{Barriers and Personal Protection Equipment (PPE)}

Personal effects that have the potential to harbour infection over a long period of time such as rings and watches should not be brought into the operatory. ${ }^{27}$

Gloves: Reports have shown that individual glove perforation rate can range from $2.1 \%$ per operation to up to $16 \%$ per operation. ${ }^{28-29}$ Unfortunately, most dental clinics worldwide seem to prefer the use of thin non sterile latex examination gloves for routine procedures citing expense involved in the use of surgical gloves. These gloves contain microscopic pores and may allow contact and passage of pathogenic organisms. Double gloving when using non sterile gloves has therefore been recommended for any clinical procedure. ${ }^{30-32}$

Disposable gloves should not be washed and/or reused for any purpose. Gloves are not to be reused, as repeated use will produce defects in the gloves, which diminishes the gloves ability to be an effective barrier. Gloves that become ripped, torn or compromised in any form must be removed as soon as possible. Hands must always be washed prior to donning new gloves. At all times, when wearing gloves, the operator must be aware of and avoid surface contact (i.e. with pens, charts, eye protection, handles, etc.). For dental procedures where contact with blood is imminent (such as first stage implant surgery and minor maxillofacial surgery), surgical gloves should be used.

Face protection: Chin length face shields, or masks and eyewear with protective side shields must be worn by the dentist and assistants when spattering of blood or other body fluids or the production of aerosols is likely such as during oral prophylaxis and procedures involving use of high speed airoter handpieces. Masks are single use only and must be disposed of properly after use. Masks that are damp (inside or out) have lost their effectiveness as a barrier and should be removed and replaced as soon as feasible.
Eye Protection: All eye protection must have side shields, either solid or slide-on type for prescription lenses and all eye protection must be disinfected between patients to avoid possible contamination or infection.

\section{Infrastructure in the Dental Office}

Structural Barriers: A structural barrier system is essentially the physical division of workflow into sections so that an infection source that enters at one point is adequately handled before the item is allowed to proceed to the next area for processing. In the dental office, receiving and shipping areas should be set up to handle material that is being sent to commercial laboratories and for products and materials that are received from these laboratories. ${ }^{33}$ Material from these areas should not be allowed to pass through the operatory and the reception. Adequate sterilisation of infectious material leaving for the dental laboratory should be handled in an area separate from the operatory so that aerosols and other by-products of inhouse processing do not contaminate the operatory.

The authors firmly believe that it is the duty of the dental surgeon to ensure that sterilisation of any infectious material is performed in his/her clinic before it is transferred to the laboratory or indicate that such disinfection or sterilisation has not been performed allowing the laboratory to take necessary cross infection procedures before performing required processing tasks.

Surface Disinfection: Surface covers prevent contamination of those surfaces that are difficult or impossible to protect. Surface covers also reduce the handling of chemical disinfectants and require less time to use. If surface covers are used, pre-cleaning and disinfection at the beginning and end of the day is adequate.

Surface covers should be utilized and not limited to the following areas:

1. The Dental chair and operator stools

2. Instrument tray and handles of the dental chair

3. Handles of the overhead dental light and switch if existing

4. Controls and head of the intra-oral x-ray unit

5. RVG Sensors and films

6. Suction and handpiece tubings. 
Commercially available gamma-sterilised surface covers are available for use in dental clinics and would be ideal for protecting surfaces that may come into contact with blood or saliva that may be difficult to disinfect. Autoclaved cloth covers may be used for cases which require an increased level of disinfection such as when performing implant first stage surgeries. Routine use of autoclaved cloth covers is a time consuming and expensive procedure for private dental clinics.

An alternative and easily implemented protocol is to use impervious backed paper, aluminium foil or plastic wrap to cover surfaces or items. The cover must be removed, discarded and then replaced between patients. Disinfection is not required between patients when surface covers are used..$^{34}$ Use of commercially available disposable patient drapes is recommended for use in private dental clinics.

Dental chair unit (DCU) manufacturers should be encouraged to adopt hand sensor controls for overhead chair lights and dentists and assistants should aim to utilize foot controls to control the chair rather than the panels located on the instrument tray holder.

Airflow Systems in the Dental Office: all equipment and personnel in the dental office are exposed to infectious aerosols created when dental hand-pieces are used..$^{35}$ Even though bacterial counts have not been shown to be significantly higher than those in public areas, a proper airflow system ensures circulation of fresh air into the operatory is maintained, to prevent potential infection from airborne microorganisms. ${ }^{36-37}$ Use of air-conditioner in a heath care setup has shown to have a positive effect on air circulation. ${ }^{38-39}$ Many small private settings do not have such facilities or run the system only when a patient is on the chair to save on running costs. Clinics which do not have airconditioners may benefit from a good form of natural ventilation and small exhaust systems.

Dental Unit water system (DUWS) Waterlines (DUWL): DCUs contain elaborate systems of interconnected plastic tubing, to provide cooling systems to dental high speed hand-pieces and burs and to prophylactic hand-pieces. These DUWL have been shown to develop microbial biofilms overnight when the DCU is not in use. The primary organisms isolated from DUWL are Gram-negative bacteria that include Legionella, Pseudomonas, and Mycobacterium species. These organisms may be transferred directly to the patients and office personnel via droplet transmission and improper maintenance of the DCUs. ${ }^{40-42}$

A recent report exists of a patient developing an acute infection following dental treatment that resulted from contaminated water lines. ${ }^{43}$ Disinfection of the DUWS has to be performed.

The microbial quality standards for potable water vary across the world with the ADA specifying $\leq 200$ cfu per millilitre of aerobic heterotrophic bacteria for DCU output water and the $\mathrm{CDC}$ recommending that the DCU output water should be $\leq 500$ cfu per millilitre of aerobic heterotrophic bacteria. In India, one should ensure that the water supplied to the DCU should be from a Class C source - "Drinking water source with conventional treatment followed by disinfection" ${ }^{44}$

Commercial waterline cleaning systems are available from DCU manufacturers which have been reported to satisfy the requirements of the ADA and the CDC. ${ }^{45}$ These systems are difficult to procure in India due to high costs.

It has been shown that peroxide, phenol, chlorite and povidone-iodine based, and hydroxide containing products and electrochemical activated agents (ECA) for disinfection of DUWLs have been able to bring about $\geq 95 \%$ removal of the biofilm. ${ }^{46-48}$ Betweenpatient disinfection of water lines has also been recommended. ${ }^{49}$ These methods would be more economically and easy to implement in private dental clinics.

\section{Materials and Instruments in the Dental Clinic}

\section{Instruments and Hand-pieces}

Dental Instruments have been classified into three categories following the Spaulding Classification critical, semi-critical, and non-critical, depending on their risk of contamination and need for sterilisation between use. 
All dental instruments and hand-pieces manufactured today are generally certified to be autoclaved for sterilisation after each use. A small number of singleuse, disposable hand-pieces are slowly emerging in the market. Studies on the effects of sterilisation on dental instruments suggest a reduction in life of the handpiece with repeated cycles of autoclaving and possible reduction in intensity of LED light curing tips. ${ }^{50-52}$ Auditing of instrument efficiency and performance in the dental office should be performed at regular intervals.

Autoclaving of dental instruments should be done utilising sealed autoclavable pouches. These pouches enable storage of the instruments in the sterilised form over a long period and also for transport to other operating sites.

Ultrasonic cleaning along with cold sterilisation has been recommended for dental instruments and burs and polishing cups to inactivate HBV. ${ }^{53-54}$ Instruments that cannot be sterilised (alcohol torches, articulators, knives, bowls and spatulas and shade/mould guides) should be disinfected by a spray or immersion technique after each use adhering to manufacturer guidelines. Air/Water Syringes and autoclavable saliva ejectors should be routinely decontaminated with a solution of 1000 ppm available chlorine in detergent after each patient. If chlorine is incompatible with the materials from which the instrument is made, an alternative virucidal agent, such as $70 \%$ isopropyl alcohol wipes, should be used. ${ }^{53}$ Autoclaving should be performed at the end of the day. We recommend the use of disposable suction tips for the private dental clinic.

Dental Impressions and casts: Dental impressions may be contaminated with the patient's blood, saliva and bacterial plaques allowing transmission of pathogens such as HBV and HIV. ${ }^{55}$ Several manufacturers have attempted to incorporate disinfectants into irreversible hydrocolloid but the quaternary ammonium compounds used have been shown to result in dermal and mucosal irritation in some patients. ${ }^{56}$ These materials are again, not easily available in India and therefore conventional methods have to be employed.
The prime concern with the decontamination of a dental impression is the maintenance of dimensional stability and the accurate reproduction of the resultant cast. Several studies have been conducted with disinfectants on this effect. ${ }^{57-63}$ Additionally polyvinyl siloxane materials have been developed that may be autoclaved without significant distortion. ${ }^{64}$

Bacterial contamination of stone casts has been demonstrated, however disinfection of stone casts can lead to alterations in the linear dimensions and surface details of the cast. ${ }^{65-66}$ It highly therefore recommended to disinfect the impression or prosthesis rather than carrying out disinfection of the cast or to use stones with incorporated disinfectants. ${ }^{67}$ Overnight gas sterilisation has been recommended for casts of patients that are suspected to carry highly infectious pathogens.

Disposal of Sharps and Waste: Sharp items such as needles and old burs should be placed in an appropriate "sharps" container. This container should be rigid, puncture-resistant, leak resistant, and closed tightly to prevent loss of contents. These containers should not be emptied and should be disposed of as soon as the contents reach the fill/full line. Alternatively needle breakers and burners, if permitted by prevailing local regulations, may be utilised to dispose of syringe needles.

Disposal of wastes should comply with state government guidelines for disposal of medical waste. The dentist would do well to make use of the services of certified commercial waste disposal firms who undertake collection and incineration of waste generated from dental clinics.

\section{Conclusions}

The potential sources of infection that plague the dental community world over are the same for dentists in India. In India, the problem seems to lie in the lack of knowledge of cross infection hazards and guidelines and available resources. The ultimate goal of all infection control activities should be designed to break a link in the chain of infection and interrupt person-to-person transmission of infection. For this to work effectively the following should be considered and adopted: 
1. Adequate education and training for students and professionals in cross infection control at the basic level in under-graduate curriculum and also in the form of Continuous Education.

2. All clinics should develop and efficiently implement their own standard operating procedures based on the standard guidelines to best suit the practice. It is recommended that all staff in the clinic be vaccinated against Hepatitis B. Booster doses should be administered to staff on a timely basis.

3. Efficient communication between all members of the team and especially between the dental office and the laboratory is essential. Members of the dental office team should not be in a position to hide lapses in infection control such as needle prick injuries or eye injury due to blood splatter and compromise their position. Untoward incidents should be reported and immediate precautionary measures should be made to protect the staff.

4. Reactive measures to immediate requirements to ensure a minimally infectious dental setting in India.

\section{References}

1. Runnels RR. An overview of infection control in dental practice. J Prosthet Dent 1988; 59(5): 625-629. http://dx.doi. org/10.1016/0022-3913(88)90083-2

2. Leggat PA, Kedjarune U, Smith DR. Occupational health problems in modern dentistry: a review. Ind Health 2007; 45(5): 611-621. http://dx.doi.org/10.2486/indhealth.45.611

3. Jeffries DJ. Viral hazards to and from health care workers. J Hosp Infect 1995; 30 Suppl: 140-155. http://dx.doi. org/10.1016/0195-6701(95)90014-4

4. Powell GL, Runnells RD, Saxon BA, Whisenant BS. The presence and identification of organisms transmitted to dental laboratories. / Prosthet Dent 1990; 64(2): 235-237.

5. Connor C. Cross-contamination control in prosthodontic practice. Int / Prosthodont 1991; 4(4): 337-344. http://dx.doi. org/10.1016/0022-3913(90)90185-F

6. Molinari JA, Merchant VA, Gleason MJ. Controversies in infection control. Dent Clin North Am 1990; 34(1): 55-69.

7. Breda-Albuquerque $F$, de Farias $A B L$, do Prado MG, OrestesCardoso S. Influence of clinican's socio-demographic, professional, and educational variables on their compliance with preventive measures against Hepatitis B and C. Oral Health Prev Dent 2008; 6(4): 349-354.

8. Monarca S, Grottolo M, Renzi D, et al. Evaluation of environmental bacterial contamination and procedures to control cross infection in a sample of Italian dental surgeries. Occup Environ Med 2000; 57(11): 721-726. http://dx.doi. org/10.1136/oem.57.11.721

9. Al-Omar MA, Al-Dwairi ZN. Compliance with Infection Control Programs in Private Dental Clinics in Jordan. J Dent Educ 2005; 69(6): 693-698.
10. Jagger DC, Hugget R, Harrison A. Cross-infection control in dental laboratories. Br Dent / 1995; 179(3): 93-96. http:// dx.doi.org/10.1038/sj.bdj.4808846

11. McCarthy GM, Koval JJ, John MA, MacDonald JK. Infection Control Practices Across Canada: Do Dentists Follow the Recommendations. J Can Dent Assoc 1999; 65(9): 506-511.

12. Gordon BL, Burke FJT, Bagg J, Marlborough HS, McHugh ES. Systematic review of adherence to infection control guidelines in dentistry. J Dent 2001; 29(8): 509-516. http://dx.doi. org/10.1016/S0300-5712(01)00043-4

13. Finer $Y$, Diwan R. Materials used in the management of edentulous patients. In Zarb G, Hobkirk JA, Eckert SE, et al. Prosthodontic treatment for edentulous patients. 13th ed. St. Louis: Mosby; 2013. 121-160.

14. Rosenstiel SF, Land MF, Fujimoto J. Communicating with the dental laboratory. In Rosenstiel SF, Land MF, Fujimoto J. Contemporary fixed prosthodontics. 4th ed. St. Louis: Mosby; 2006. 510.

15. Anusavice KJ, Phillips RW, Shen C, Rawls R. Phillips' Science of Dental Materials. 12th ed.: Elsevier Health Sciences; 2012.

16. Kohn WG, Collins AS, Cleveland JL, Harte JA, Eklund KJ, Malvitz DM. Guidelines for infection control in dental healthcare settings - 2003. MMWR 2003; 52(RR17): 1-61.

17. American Dental Association. Infection control recommendations for the dental office and the dental laboratory ADA Council on Scientific Affairs and ADA Council on Dental Practice. J Am Dent Assoc 1996; 127(5): 672-680. http://dx.doi.org/10.14219/jada.archive.1996.0280

18. US Department of Labor, Occupational Safety and Health Administration. Controlling occupational exposure to bloodborne pathogens, OSHA 3127 (revised).

19. Ajayi YO, Ajayi EO. Dental students' knowledge of human immunodeficiency virus. J Dent 2008; 36(5): 374-378. http:// dx.doi.org/10.1016/j.jdent.2008.02.008

20. Petti S, Messano GA, Polimeni A. Dentists' awareness toward vaccine preventable diseases. Vaccine 2011; 29(45): 81088112. http://dx.doi.org/10.1016/j.vaccine.2011.08.034

21. McCarthy GM, Britton JE. A survey of final-year dental, medical and nursing students: occupational injuries and infection control. J Can Dent Assoc 2000; 66(10): 561.

22. Kitaura H, Adachi N, Kobayashi K, Yamada T. Knowledge and attitudes of Japanese dental health care workers towards HIVrelated disease. J Dent 1997; 25(3-4): 279-283. http://dx.doi. org/10.1016/S0300-5712(96)00030-9

23. Puttaiah R, Shetty S, Bedi R, Verma M. Dental infection control in India at the turn of the century. World Journal of Dentistry 2010; 1(1): 1-6.

24. Singh BP, Khan SA, Agrawal N, Siddarth R, Kumar L. Current biomedical waste management practices and crossinfection control procedures of dentists in India. Int Dent I 2012; 62(3): 111-116. http://dx.doi.org/10.1111/j.1875595X.2011.00100.x

25. Sudhakar V, Chandrashekar J. Dental health care waste disposal among private dental practices in Bangalore City, India. Int Dent J 2008; 58(1): 51-54.

26. Miller $\mathrm{CH}$, Palenik Cl. Infection Control Rationale and Regulations. In Miller CH, Palenik C). Infection control and management of hazardous materials for the dental team. 4th ed. St. Louis: Mosby; 2010.

27. Field AE, McGowan P, Pearce PK, Martin MV. Rings and watches: should they be removed prior to operative dental procedures? / Dent 1996; 24(1-2): 65-69. http://dx.doi. org/10.1016/0300-5712(95)00038-0 
28. Avery CME, Hjort A, Walsh S, Johnson PA. Glove perforation during surgical extraction of wisdom teeth. Oral Surg Oral Med Oral Pathol Oral Radiol Endod 1998; 86(1): 23-25. http:// dx.doi.org/10.1016/S1079-2104(98)90144-5

29. Burke FJT, Baggett FJ, Lomax AM. Assessment of the risk of glove puncture during oral surgery procedures. Oral Surg Oral Med Oral Pathol Oral Radiol Endod 1996; 82(1): 18-21. http:// dx.doi.org/10.1016/S1079-2104(96)80372-6

30. Field EA. The use of powdered gloves in dental practice: a cause for concern? J Dent 1997; 25(3-4): 209-214. http:// dx.doi.org/10.1016/S0300-5712(96)00013-9

31. Tinsley D, Chadwick RG. The permeability of dental gloves following exposure to certain dental materials. I Dent 1997; 25(1): 65-70. http://dx.doi.org/10.1016/0300-5712(95)00124-

32. Tanner J, Parkinson H. Double gloving to reduce surgical crossinfection. Cochrane Database Syst Rev 2006; (3): CD003087.

33. Palenik CJ. Dental Laboratory Asepsis. Dentistry Today 2005; [cited 2013 July 16] Available from: http://www.dentistrytoday. com/infection-control/1325.

34. The Ohio State Dental Board. Infection Control Manual. Infection Control. Columbus, Ohio: The Ohio State Dental Board; 2011.

35. Rautemaa R, Nordberg A, Wuolijoki-Saaristo K, Meurman $\mathrm{JH}$. Bacterial aerosols in dental practice - a potential hospital infection problem? J Hosp Infect 2006; 64(1): 76-81. http:// dx.doi.org/10.1016/j.jhin.2006.04.011

36. Kimmerle $\mathrm{H}$, Wiedmann-Al-Ahmad M, Pelz K, Wittmer A, Hellwig E, Al-Ahmad A. Airborne microbes in different dental environments in comparison to a public area. Arch Oral Biol 2012; 57(6): 689-696. http://dx.doi.org/10.1016/j. archoralbio.2011.11.012

37. Tang JW, Noakes CJ, Nielsen PV, et al. Observing and quantifying airflows in the infection control of aerosol- and airborne-transmitted diseases: an overview of approaches. I Hosp Infect 2011; 77(3): 213-222. http://dx.doi.org/10.1016/j. jhin.2010.09.037

38. Mohta M. If air conditioning is not functioning. Indian / Anaesth 2010; 54(6): 580. http://dx.doi.org/10.4103/00195049.72657

39. Ghaus MS. Air-conditioning for infection control. Indian J Anaesth 2011; 55(3): 322. http://dx.doi.org/10.4103/00195049.82674

40. Coleman DC, O' Donnell MJ, Shore AC, Russell RJ. Biofilm problems in dental unit water systems and its practical control. J Appl Microbiol 2009; 106(5): 1424-1437. http://dx.doi. org/10.1111/j.1365-2672.2008.04100.x

41. Pankhurst $\mathrm{CL}$, Coulter WA. Do contaminated dental unit waterlines pose a risk of infection. J Dent 2007; 35(9): 712720. http://dx.doi.org/10.1016/j.jdent.2007.06.002

42. O' Donnell MJ, Tuttlebee CM, Falkiner FR, Coleman DC. Bacterial contamination of dental chair units in a modern dental hospital caused by leakage from suction system hoses containing extensive biofilm. J Hosp Infect 2005; 59(4): 348360. http://dx.doi.org/10.1016/j.jhin.2004.10.001

43. Bhandary N, Bhandary S. Melioidosis in dental practice - Case reports. Endodontology 2011; 23(1): 82-85.

44. Central Water Commission. Tolerance and Classification with respect to various water uses. Bureau of Indian Standards (BIS); 2010.

45. O' Donnell MJ, Shore AC, Coleman DC. A novel automated waterline cleaning system that facilitates effective and consistent control of microbial biofilm contamination of dental chair unit waterlines: A one-year study. I Dent 2006; 34(9): 648-661. http://dx.doi.org/10.1016/j.jdent.2005.12.006
46. Walker JT, Bradshaw DJ, Fulford MR, Marsh PD. Microbiological evaluation of a range of disinfectant products to control mixed-species biofilm contamination in a laboratory model of a dental unit water system. Appl Environ Microbiol 2003; 69(6): 3327-3332. http://dx.doi.org/10.1128/AEM.69.6.33273332.2003

47. Tuttlebee CM, O'Donnell MJ, Keane CT, et al. Effective control of dental chair unit waterline biofilm and marked reduction of bacterial contamination of output water using two peroxidebased disinfectants. J Hosp Infect 2002 Nov; 52(3): 192-205. http://dx.doi.org/10.1053/jhin.2002.1282

48. O' Donnell MJ, Russell RK, Swan J, Russel RJ, Coleman DC. A centralised, automated dental hospital water quality and biofilm management system using neutral Ecasol maintains dental unit waterline output at better than potable quality: A 2-year longitudinal study. J Dent 2009; 37(10): 748-742. http://dx.doi.org/10.1016/j.jdent.2009.06.001

49. Montebugnoli L, Chersoni S, Prati C, Dolci G. A betweenpatient disinfection method to control water line contamination and biofilm inside dental units. J Hosp Infect 2004; 56(4): 297-304. http://dx.doi.org/10.1016/j.jhin.2004.01.015

50. Al Saafi MM. Effects of different infection control methods on the intensity output of LED Light-Curing Units. King Saud University Journal of Dental Sciences 2013; 4(1): 27-31. http:// dx.doi.org/10.1016/j.ksujds.2012.11.005

51. Worthington L, Martin MV. An investigation of the effect of repeated autoclaving on the speed of some dental turbines in general dental practice. / Dent 1998; 26(1): 75-77. http:// dx.doi.org/10.1016/S0300-5712(96)00073-5

52. Clappison RA. Cross contamination control and the dental handpiece. / Prosthet Dent 1995; 73(5): 492-494. http:// dx.doi.org/10.1016/S0022-3913(05)80081-2

53. Weightman NC, Lines LD. Problems with the decontamination of dental handpieces and other intra-oral dental equipment in hospitals. J Hosp Infect 2004; 56(1): 1-5. http://dx.doi. org/10.1016/j.jhin.2003.09.006

54. Leontiou AP, Coogan MM, Aspinall S. Disinfection of dental diamond burs contaminated with hepatitis B virus. I Prosthet Dent 1999; 82(3): 332-335. http://dx.doi.org/10.1016/S00223913(99)70100-9

55. Al-Jabrah O, Al-Shumailan Y, Al-Rashdan M. Antimicrobial effect of 4 disinfectants on alginate, polyether, and polyvinylsiloxane impression materials. Int J Prosthodont 2007; 20(3): 299-307.

56. Baker PS, Plummer KD, Parr GR, Parker MH. Dermal and mucosal reactions to an antimicrobial irreversible hydrocolloid impression material: A clinical report. / Prosthet Dent 2006; 95(3): 190-193. http://dx.doi.org/10.1016/j. prosdent.2006.01.008

57. Suprono MS, Kattadiyil MT, Goodacre CJ, Winer MS. Effect of disinfection on irreversible hydrocolloid and alternative impression materials and the resultant gypsum casts. J Prosthet Dent 2012; 108(4): 250-258. http://dx.doi.org/10.1016/ S0022-3913(12)60173-5

58. Rentzia A, Coleman DC, O' Donnell MJ, Dowling AH, O' Sullivan M. Disinfection procedures: Their efficacy and effect on dimensional accuracy and surface quality of an irreversible hydrocolloid impression material. J Dent 2011; 39(2): 133140. http://dx.doi.org/10.1016/j.jdent.2010.11.003

59. Martin N, Martin MV, Jedynakiewicz NM. The dimensional stability of dental impression materials following immersion in disinfecting solutions. Dent Mater 2007; 23(6): 760-768. http://dx.doi.org/10.1016/j.dental.2007.01.004 
60. Taylor RL, Wright PS, Maryan C. Disinfection Procedures: their effect on the dimensional accuracy and surface quality of irreversible hydrocolloid impressions and gypsum cast. Dent Mater 2002; 18(2): 103-110. http://dx.doi.org/10.1016/ S0109-5641(01)00027-6

61. Thouati A, Deveaux E, lost A, Behin P. Dimensional stability of seven elastomeric impression materials immersed in disinfectants. J Prosthet Dent 1996; 76(1): 8-14. http://dx.doi. org/10.1016/S0022-3913(96)90338-8

62. Johnson GH, Chellis KD, Gordon GE, Lepe X. Dimensional stability and detail reproduction of irreversible hydrocolloid and elastomeric impressions disinfected by immersion. J Prosthet Dent 1998; 79(4): 446-453. http://dx.doi. org/10.1016/S0022-3913(98)70160-X

63. Lepe X, Johnson GH, Berg JC. Surface characteristics of polyether and addition silicone impression materials after long-term disinfection. J Prosthet Dent 1995; 74(2): 181-186. http://dx.doi.org/10.1016/S0022-3913(05)80184-2
64. Surendra GP, Anjum A, Satish Babu CL, Shetty S. Evaluation of Dimensional Stability of Autoclavable Elastomeric Impression Material. J Indian Prosthodont Soc 2011; 11(1): 63-66. http:// dx.doi.org/10.1007/s13191-011-0061-1

65. Mitchell DL, Hariri NM, Duncanson MG, Jacobsen NL, McCallum RE. Quantitative study of bacterial colonization of dental casts. J Prosthet Dent 1997; 78(5): 518-521. http:// dx.doi.org/10.1016/S0022-3913(97)70069-6

66. Abdullah MA. Surface detail, compressive strength, and dimensional accuracy of gypsum casts after repeated immersion in hypochlorite solution. J Prosthet Dent 2006; 95(6): 462468. http://dx.doi.org/10.1016/j.prosdent.2006.03.019

67. Pereira RP, Lucas MG, Spolidorio DM, Arioli FJ. Antimicrobial activity of disinfectant agents incorporated into type IV dental stone. Gerodontology 2012; 29(2): e267-74. http://dx.doi. org/10.1111/j.1741-2358.2011.00462.x 